\title{
Effect of Drying Methods on Edible Film Properties
}

\author{
Marwa M. Helmy, Omar S. Younes and Manal A. Sorour
}

Food Engineering and Packaging Department, Food Technology Research Institute, Agricultural Research Center, Egypt

Received: 10 Oct. 2019/Accepted 20 Dec. 2019 / Publication date: 30 Dec. 2019

\begin{abstract}
Two different methods of drying (electric dryer and solar energy dryer) were used to dry edible films prepared from CMC with the addition of thyme oil. Different samples of edible films were characterized by measuring thickness, water vapor and gas permeability, water solubility, mechanical properties and transparency. The results indicated that time of drying by solar energy decreased by $70-72 \%$ with respect to electric dryer. However, the addition of oil increased time of drying for both methods (electric dryer and solar drying). Different properties of edible films dried using electric dryer and solar dryer were measured, the results observed that solar drying has an effect on $\mathrm{O}_{2} \mathrm{CO}_{2}$, water vapor permeability, transmittance rate and tensile strength. The higher tensile strength was observed for control sample $2 \% \mathrm{CMC}(48.676 \mathrm{~N})$ dried using solar dryer, on the other hand, $\mathrm{CO}_{2}$ and water vapor permeability for edible film samples dried using solar dryer increased with respect to electric dryer and vice versa oxygen permeability. Edible film dried using solar dryer has better transmittance rate than samples dried using electric dryer.
\end{abstract}

Keywords: drying of edible films, moisture content, solar dryer, gas and water vapor permeability

\section{Introduction}

Drying by solar energy is a rather economical procedure for agricultural products, especially for medium to small amounts of products, to preserve excess of production. It is friendly to the environment.

Use of an edible film has been a popular preservation application in recent years because it is more economical and easier procedure compared to other postharvest treatment methods. It works to control a modified internal gas composition and protective barrier that retards dehydration, improves textural quality, and reduces microbial growth by forming a thin film layer of edible, natural, and biodegradable substances on fresh produce. The use of edible coatings has shown good efficiency in extending the freshness of strawberries, pomegranates, and tomatoes (Nandane and Jain, 2011).

An essential oil (EO) is an organophilic material obtained from the flowers, fruits, seeds, bark, roots, leaves or other parts of a plant. It is processed commercially for its fragrance and antimicrobial properties (Baser and Buchbauer, 2015). In food applications, the essential oils have been employed extensively as natural antimicrobial additives.

In food applications, one of the popular topics today is active packaging. This refers to packaging systems used with foods that help extend shelf life, maintain freshness and quality, improve microbial safety, and enhance convenience (Oliveira et al., 2017). In other words, the packaging material should have active functions beyond the simple containment and physical / barrier protection of food product. A good example of active packaging is to embed an antimicrobial material directly into the packaging film, which can decrease microbial activity and ensure food safety (Otoni et al., 2014 and Oliveira et al., 2017).

The objective of the present paper is the preparation of edible film using two methods of drying (electric dryer and solar drying) and compares the properties of the produced edible films.

\section{Material and Methods}

\section{Material}

Carboxy Methyl Cellulose (CMC) and glycerol were purchased from Acematic company, while thyme oil (ThO) was purchased from Egyptian market

Corresponding Author: Omar S. Younes, Food Engineering and Packaging Department, Food Technology Research Institute, Agricultural Research Center, Egypt.

E-mail: oshahat@hotmail.com 


\section{Methods}

\section{Design of the solar energy dryer}

A solar dryer was designed at Food Engineering and Packaging Department Food Technology Research Institute, ARC as shown in figure (1):

- Dimensions $(1 \mathrm{~m})$ length $\mathrm{x}(0.96 \mathrm{~m})$ width $\mathrm{x}(0.95 \mathrm{~m})$ height

- Three different solar collectors, each of which consists of a double wall (the upper surface is a transparent glass that allows the entry of short waves solar radiation to the lower surface, the lower surface is a black sheet winding and works to absorb solar radiation and convert it to long waves thermal energy.

1.The first collector is the top surface of the dryer and is inclined $30^{\circ}$ with the south horizontal direction.

2.The second collector is the vertical side of the dryer towards east.

3. The third collector is the vertical side of the dryer towards the west.

- The back side of the dryer is a double-walled door of black iron sheet, including glass wall as a thermal insulation to prevent heat leakage outside the dryer.

- Trolley equipped with (4) trays of stainless steel was assigned to carry solution of edible film to be dried.

- Suction fan was used to carry moist air to a chimney containing silica gel filter in order to absorb moisture.

- Fan works for circulation of hot air inside the dryer cabin.
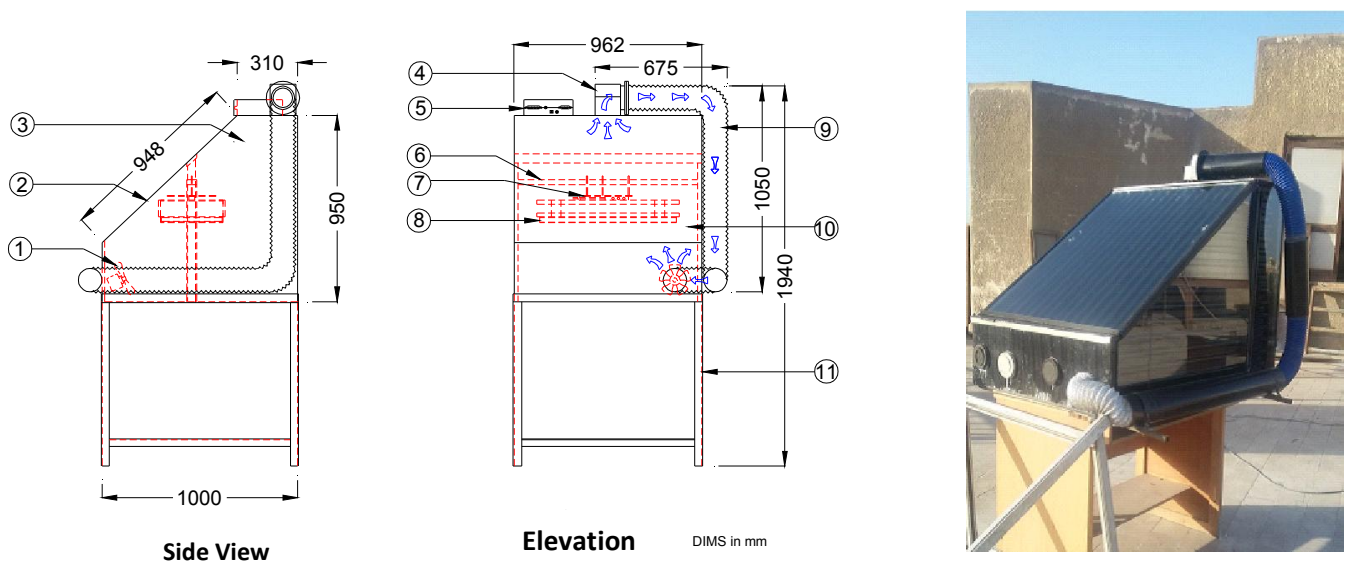

Fig. 1: Solar dryer

1-Fan, 2-The oblique solar collector, 3-Vertical collector, 4-Ventilatore, 5- Data logger, 6-Weight balance holder, 7- Weight balance 8- tray, 9- filter, 10- air bath, 11-dryer stand.

\section{Electric dryer}

Samples of edible films were dried using electric hot air dryer model (Venticell) installed in Department of Food Engineering, Food Technology Research Institute, ARC.

\section{Preparation of Carboxy methyl cellulose (CMC) films}

Carboxy methyl cellulose (CMC) with $2 \%$ concentration was prepared by dissolving CMC in distilled water with stirring for one hour and adding different concentrations of thyme oil (ThO) (0.5, $1.0,1.5,2.0 \%$ ) during stirring, glycerol was added as Plasticizer (1\%). The prepared solutions were poured into petri dishes and dried in electric dryerat $50^{\circ} \mathrm{C}$ until the weight of the dried film became stable. Also, anther blends was dried using solar energy, after which CMC films were peeled off manually. 


\section{Drying procedure}

Edible solutions were transferred into a laboratory scale electric hot-air and solar dryer, weight loss of samples was recorded at one hour intervals during drying until it reaches the equilibrium condition. The drying process using the solar dryer was conducted during July 2018. For estimating the moisture content, reduction in the mass of edible films is observed. The net variation between initial and final moisture content of the film provide statistics about the moisture content, according to the formula used by (Soltani et al., 2014).

Moisture Content W.B $(\%)=\frac{W-W_{d}}{\mathrm{~W}} \times 100$

Where, $\mathrm{W}=$ the weight of film before drying, $\mathrm{gm}$ and $\mathrm{W}_{\mathrm{d}}=$ The weight of film after drying, $\mathrm{gm}$

\section{Equipment Measurements}

Data Logger specifications

Weight Unit specifications

$\begin{array}{ll}\text { Capacity } & \text { Ranges from } 0.001 \mathrm{Kg} \text { to } 40 \mathrm{KG} \\ \text { Operating temperature range } & -20 \text { to } 80^{\circ} \mathrm{C} \\ \text { Accuracy } & 0.01 \mathrm{~g} \\ \text { Cable length } & 3 \mathrm{~m}(10 \mathrm{ft}) \\ \text { Material } & \text { The GCB3 is constructed of anodized aluminum and is } \\ & \text { environmentally sealed against humidity }\end{array}$

Air relative humidity sensor specifications

\begin{tabular}{ll}
\hline Type & DHT22 \\
Power supply & $3.3-6 \mathrm{~V}$ DC \\
Measuring range & $0-100 \%$ RH \\
Accuracy & $\pm 2 \%$ \\
\hline
\end{tabular}

Air Temperature sensor specifications

\begin{tabular}{ll}
\hline Type & $\mathrm{K} 0603$ \\
Power supply & $3.3-6 \mathrm{~V}$ DC \\
Measuring range & -40 to $+350^{\circ} \mathrm{C}$ \\
Accuracy & $\pm 0.2^{\circ} \mathrm{C}$ \\
\hline
\end{tabular}

Solar power meter specifications

\begin{tabular}{ll} 
Type & DDSY5558 \\
Power supply & $3.3 \mathrm{~V}-6 \mathrm{~V}$ DC \\
Measuring range & $10-2500$ Watt \\
Accuracy & \pm 5 Watt \\
\hline
\end{tabular}

\section{Characterization of edible film}

\section{Film thickness}

Film thickness was measured using a Mitutoyo micrometer (Model MDC-25M, MFG / Japan). The final value represented the average of 10 random measurements taken at different parts of the film.

\section{Mechanical properties}

The mechanical properties (Tensile strength and elongation at break) were determined using Texure analyser $\mathrm{C} 3$. The samples were clamped between pneumatic grips and force $(\mathrm{N}) 10-50 \mathrm{KN}$. 


\section{Measurement of transparency}

The transparency of the film was estimated using spectrum transmission meter (IS108), visible light at 550nm.

\section{Determination of solubility in water}

The solubility in water was computed as the percentage of dry matter of the solubilized film after immersion in water at $25 \pm 2^{\circ} \mathrm{C}$ for $24 \mathrm{~h}$ (Gontard et al., 1992). Film discs (diameter $2 \mathrm{~cm}$ ) were cut, weighed, immersed in $50 \mathrm{~mL}$ of distilled water, and slowly and periodically agitated. The moisture content of the films was determined gravimetrically by placing the samples in an electric dryer at $105^{\circ} \mathrm{C}$ for $24 \mathrm{~h}$.

Solubility $(\%)=\frac{\text { Initial dry weight }- \text { Final dry weight }}{\text { Initial dry weight }} \times 100$

\section{Determination of Water vapor permeability (WVP)}

The water vapor transmission rate (WVTR) $\left[\mathrm{g} /\left(\mathrm{s} . \mathrm{m}^{2}\right)\right]$ and water vapor permeability (WVP) through the produced films were determined gravimetrically using the ASTM Method E96-95. A circular test cup was used to determine the WVP of the film. The film was first cut into circular shape that was larger than the inner diameter of the cup, the cup was filled with $50 \%$ distilled water and the film was sealed at the top using Paraffin oil, then the cups were placed in a desiccators containing calcium chloride with relative humidity $\mathrm{RH}$ ( about $0 \%$ ) and $\mathrm{RH}$ for water (100\%). The weights of the cups were recorded every hour during 10 hours and to specimens of each film were tested. Linear regression was used to estimate the slope of this line in $\mathrm{g} / \mathrm{h}$. The water vapor transmission rate (WVTR) and water vapor permeability (WVP) were determined using the following relationships:

$$
\begin{gathered}
W V T R=\frac{\Delta m}{\Delta t A} \ldots \\
W V P=\frac{W V T R \times L}{\Delta R H}
\end{gathered}
$$

Where, $\frac{\Delta m}{\Delta t A}$ is the moisture gain weight per time $(\mathrm{g} / \mathrm{s}), \mathrm{A}$ is the surface area of the film $\mathrm{m}^{2}, \mathrm{~L}$ is the film thickness $(\mathrm{mm})$ and $\Delta R H$ is the difference in relative humidity.

\section{Measurement of gas Permeability}

Permeability of $\mathrm{O}_{2}$ and $\mathrm{CO}_{2}$ gases at $30^{\circ} \mathrm{C}$ was measured in a designed stainless steel cell using a gas testing instrument model Witt Oxybaby headspace gas analyser $\left(\mathrm{O}_{2} / \mathrm{CO}_{2}\right)$ following the method described by García et al., (2000); Khaled and Manal, (2019). The gas permeability (P) was calculated according to the following equation:

$$
P=\frac{Q . X}{\text { A.t. } \Delta P}
$$

Where, $\mathrm{P}$ is the permeability of gas, $\left(\mathrm{m}^{3} / \mathrm{m}\right.$.day. $\left.\mathrm{mmHg}\right), \mathrm{Q}$ is the quantity of gas diffused $\mathrm{m}^{3}, \mathrm{X}$ is the thickness of film, $\mathrm{m}, \mathrm{A}$ area of the film, $\mathrm{m}^{2}, \mathrm{t}$ is the time, day and $\Delta \mathrm{P}$ is the pressure difference across the film, $\mathrm{mmHg}$.

\section{Results and Discussion}

\section{Drying of edible film}

Different samples of CMC 2\% film and CMC 2\% with ThO $(0.5,1.0,1.5$ and $2.0 \%)$ were dried using solar energy and electric energy dryers. Figures $(2,3)$ illustrate the curves obtained for the drying kinetics of different samples of edible films dried using solar energy dryer and the electric. The variation of moisture content with drying time was obtained at $\left(50^{\circ} \mathrm{C}\right)$ for the electric dryer and $(31-$ 
$80^{\circ} \mathrm{C}$ ) for the solar dryer. Figures $(4,5)$ show the variations in both the temperature and relative humidity inside the solar dryer and the ambient air. As well, the average solar radiation is varying in the range from $199 \mathrm{~W} / \mathrm{m}^{2}$ to $1037 \mathrm{~W} / \mathrm{m}^{2}$ during the day times. It was observed that the drying rate decreased continuously throughout the drying period. The drying of films took place in the falling rate period for all samples studied. As shown in figure (3) drying time for edible film dried using electric dryer were 660, 720, 780, 840 and $900 \mathrm{~min}$ for (CMC 2\%) and CMC 2\% incorporated with (ThO) $(0.5,1.0,1.5$ and $2.0 \%)$ respectively. While for edible film dried using solar drying method the corresponding drying time were 540, 600, 660, 720 and $780 \mathrm{~min}$ for (CMC 2\%) and CMC 2\% incorporated with (ThO) $0.5,1.0,1.5$ and $2.0 \%$ ) respectively. Therefore, solar drying decreased time of drying films. Also, the addition of thyme oil increased time of drying films for both methods (electric dryer and solar dryer).

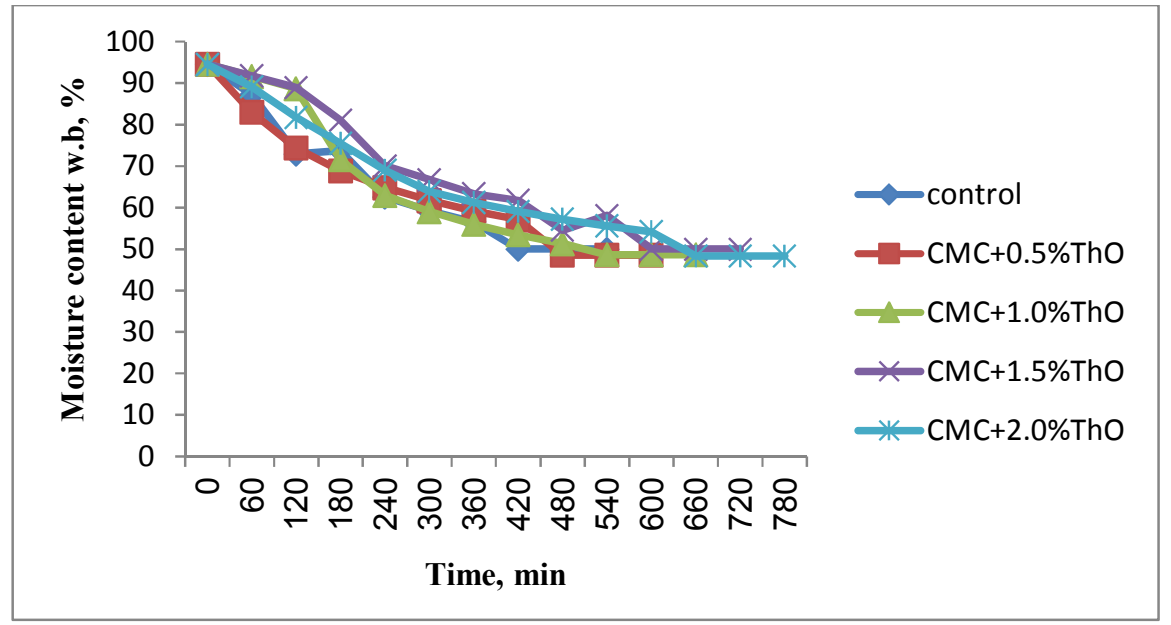

Fig. 2: Drying curve of different edible films dried using solar dryer.

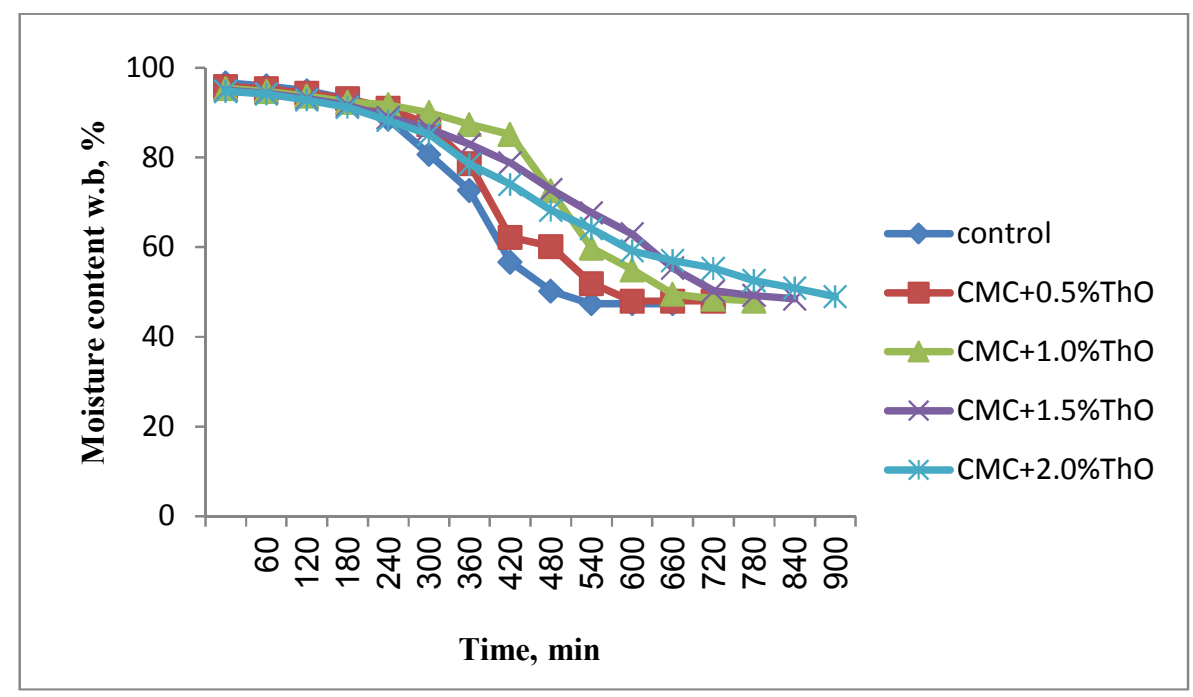

Fig. 3: Drying curve of different edible film dried using electric dryer. 


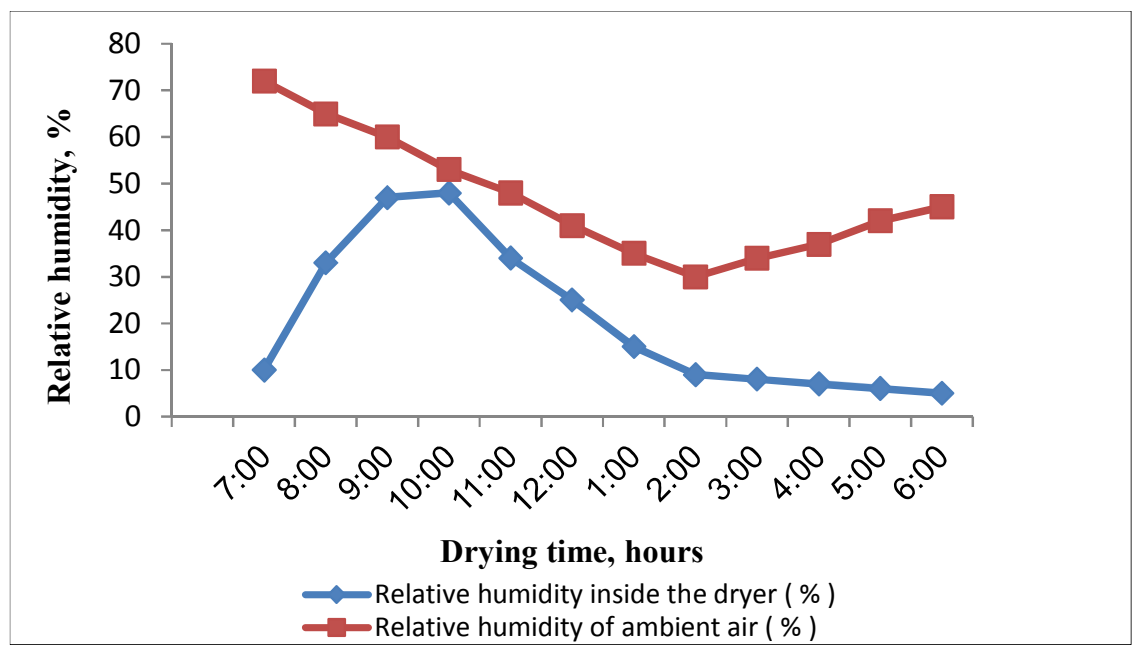

Fig. 4: The relative humidity variation with time for solar dryer.

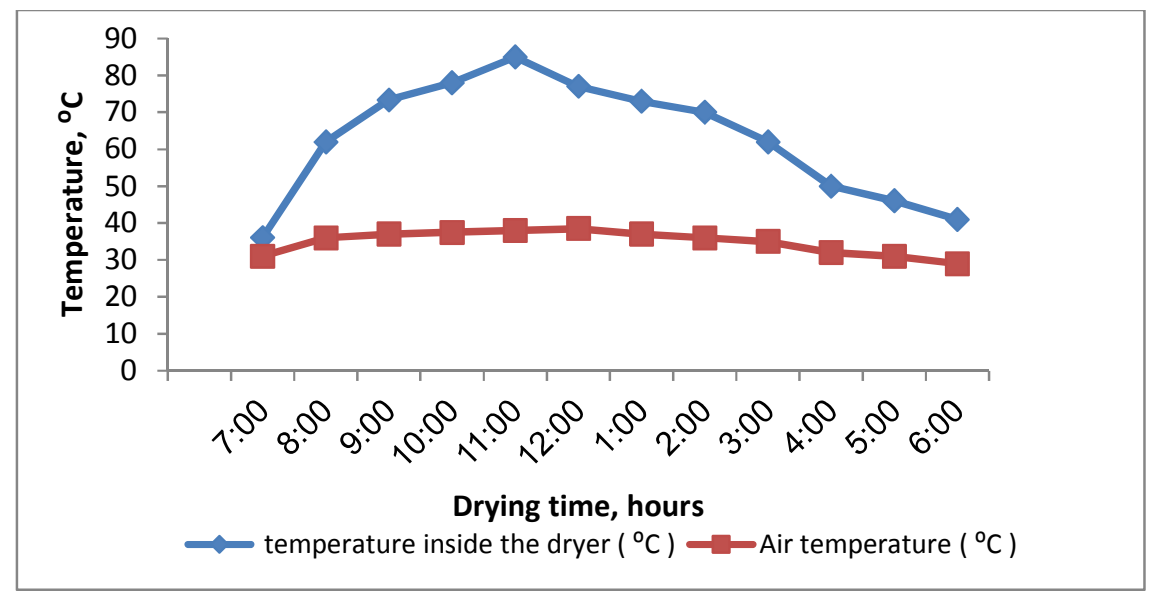

Fig. 5: The temperature variation with time for the solar dryer.

\section{Characterization of edible film}

Edible films prepared from CMC (2\%) and CMC with the addition of different concentrations of thyme oil $(0.5,1,1.5$ and $2 \%)$ were dried using solar energy and electric dryer.

The specifications of the produced edible films could be summarized as follows

\section{Thickness of edible film}

Thickness is a crucial parameter for the calculation of mechanical and barrier properties. It depends on the film preparation method, the flatness of the dish surface and the film formation during the drying process, Kokoszka et al., (2010).

Table (1) shows that thickness of CMC 2\% and CMC $2 \%$ with $\mathrm{ThO}(0.5,1.0,1.5$ and $2.0 \%)$ edible films dried using electric dryer increased with increasing concentration of thyme oil, while samples dried using solar energy did not give a good trend with increasing thyme oil it may be due to the flatness of dish surface during drying using the solar dryer. 
Table 1: Thickness of edible film samples.

\begin{tabular}{lcc}
\hline Samples & $\begin{array}{c}\text { Thickness, } \mathbf{m m} \\
\text { For electric dryer drying } \\
\text { method }\end{array}$ & $\begin{array}{c}\text { Thickness, } \text { mm } \\
\text { For solar drying method }\end{array}$ \\
\hline CMC 2\% & 0.213 & 0.113 \\
CMC2\%+0.5\% ThO & 0.259 & 0.114 \\
CMC2\%+1.0\% ThO & 0.252 & 0.102 \\
CMC2\%+1.5\% ThO & 0.338 & 0.198 \\
CMC2\%+2.0\% ThO & 0.580 & 0.174 \\
\hline
\end{tabular}

\section{Mechanical properties of edible film}

The mechanical properties of the edible films are of great importance due to their influence on product performance. Edible films as food packaging function to protect food during handling, transportation and marketing require high tensile strength. (Suppaku, 2006)

Mechanical properties (tensile strength and elongation percent) of edible films that prepared from CMC (2\%) and CMC (2\%) with ThO $(0.5,1.0,1.5$ and $2.0 \%)$ are measured and analysed. For control sample (CMC 2\%), the results showed that tensile strength of (CMC 2\%) was higher for samples dried using solar dryer with respect to electric dryer, while elongation percent was less using the solar dryer (28.375\%) with respect to electric dryer. Tensile strength and elongation percent for samples CMC with the addition of thyme oil did not give a good trend as shown in table (2), whereas higher tensile strength was recorded for sample CMC $2 \%+0.5 \%$ ThO $(41.6206 \mathrm{~N})$ using solar dryer and lower tensile strength was for the sample prepared by CMC $2 \%+1 \%(\mathrm{ThO})(12.4068 \mathrm{~N})$ using the electric dryer. A higher elongation percent was also found recorded for the prepared from CMC $2 \%+2 \%$ ThO $(22 \%)$ and a lower one was recorded for the sample prepared from CMC $2 \%+0.5 \%$ (ThO) using solar dryer energy. The decrease of tensile strength in some samples may be due to the partial replacement of stronger polymer-polymer interactions by weaker polymer-oil interactions in the network of films incorporated with essential oil. This may weaken the network structure, and hence caused a decrease in the tensile strength, (Nooshin et al., 2017).

Table 2: Mechanical properties of edible films dried using the solar dryer and the electric dryer.

\begin{tabular}{lcccc}
\hline Samples & $\begin{array}{c}\text { Tensile, } \mathbf{N} \\
\text { For electric } \\
\text { drying }\end{array}$ & $\begin{array}{c}\text { Tensile, } \mathbf{N} \\
\text { For solar drying }\end{array}$ & $\begin{array}{c}\text { Elongation, \% } \\
\text { For electric } \\
\text { drying }\end{array}$ & $\begin{array}{c}\text { Elongation, \% } \\
\text { For solar drying }\end{array}$ \\
\hline CMC 2\% & 35.2900 & 48.6766 & 24.740 & 28.375 \\
CMC2\%+0.5\% ThO & 36.5834 & 41.6206 & 6.375 & 3.500 \\
CMC2\%+1.0\% ThO & 12.4068 & 19.2374 & 5.500 & 6.250 \\
CMC2\%+1.5\% ThO & 23.5690 & 20.0802 & 12.750 & 18.000 \\
CMC2\%+2.0\% ThO & 41.6892 & 38.3670 & 19.125 & 22.000 \\
\hline
\end{tabular}

\section{Transparency of edible films}

Transparency acts as an additional factor to exploit the constituents of edible film (Liu and Zhang, 2006). Transmittance to visible light was measured at wavelength $550 \mathrm{~nm}$, the results showed that transmittance for edible film samples using the solar dryer were higher than transmittance for the samples dried using the electric dryer as shown in table (3). The addition of thyme oil to CMC edible solution decreased the transmittance rate for edible film when compared to control sample CMC $2 \%$ for both design methods.

Table 3: Film opacity (A550/mm) values for the CMC $2 \%$ and CMC $2 \%$ with ThO edible films.

\begin{tabular}{lcc}
\hline Samples & $\begin{array}{c}\text { Transmittance for electric } \\
\text { drying, \% }\end{array}$ & $\begin{array}{c}\text { Transmittance for solar drying, } \\
\text { \% }\end{array}$ \\
\hline CMC 2\% & 82.5 & 84.0 \\
CMC2\%+0.5\% ThO & 67.8 & 79.6 \\
CMC2\%+1.0\% ThO & 70.0 & 77.9 \\
CMC2\%+1.5\% ThO & 62.3 & 63.1 \\
CMC2\%+2.0\% ThO & 74.0 & 74.4 \\
\hline
\end{tabular}




\section{Water vapor permeability for different edible films}

One of the main functions of food packaging to avoid or minimize moisture transfer between the food and the surrounding atmosphere, water vapor permeability should be as low as possible in order to optimize the food package environment and potentially increase shelf life of the food product.

Water vapor permeability (WVP) of different edible films dried with solar energy and electric dryer was shown in table (4). The results observed that WVP was higher value in drying using electric dryer than solar dryer, while the higher WVP was for sample prepared from CMC $2 \%+2 \%$ ThO $\left(1.339\right.$ g. $\mathrm{mm} / \mathrm{m}^{2}$. day. $\left.\mathrm{mmHg}\right)$ using electric drying method and the lower WVP was for CMC $2 \%$ using the solar dryer $\left(0.334 \mathrm{~g} . \mathrm{mm} / \mathrm{m}^{2}\right.$. day. $\left.\mathrm{mmHg}\right)$. Basically there are two factors playing an important role. First, the addition of ThO and glycerol can increase molecular mobility and facilitate the migration of water vapor molecules, thereby increasing WVP. Secondly, the presence of the hydrophobic ThO (especially at higher dosages) can cause discontinuities in the hydrophilic polymer phase, thus increasing the tortuosity for mass transfer in the continuous matrix and decreasing WVP (Atanu et al., 2018).

Table 4: Water vapor permeability for edible films.

\begin{tabular}{|c|c|c|}
\hline \multirow{2}{*}{ Samples } & \multicolumn{2}{|c|}{ Water vapor permeability, (g. $\mathrm{mm} / \mathrm{m}^{2}$. day. $\mathrm{mmHg}$ ) } \\
\hline & Using solar drying & Using electric drying \\
\hline СМС 2\% & 0.334 & 0.476 \\
\hline CMC2\%+0.5\% ThO & 0.503 & 0.682 \\
\hline CMC2\%+1.0\% ThO & 0.655 & 1.054 \\
\hline CMC2\%+1.5\% ThO & 0.525 & 0.833 \\
\hline CMC2\% $2 \%+2.0$ ThO & 0.458 & 1.339 \\
\hline
\end{tabular}

\section{Gas Permeability}

Gas barrier properties should be taken into account. Furthermore, the incorporation of other compounds, such as essential oils, into the polymer matrix could contribute to the modification of their barrier behavior.

Gas permeability was measured for different samples of CMC $2 \%$ and $\mathrm{CMC} 2 \%$ with $\mathrm{ThO}$ $0.5,1.0,1.5$ and $2.0 \%$. The results observed that $\mathrm{O}_{2}$ permeability for edible films dried using solar energy was less than samples dried using the electric dryer and vice versa of $\mathrm{CO}_{2}$ permeability. Also table (5) shows samples with the addition of thyme oil had less $\mathrm{O}_{2}$ and $\mathrm{CO}_{2}$ permeability than control one. The lower $\mathrm{O}_{2} \mathrm{P}$ and $\mathrm{CO}_{2} \mathrm{P}$ was for samples prepared from (CMC $2 \%+2 \% \mathrm{ThO}$ ), while the higher $\mathrm{O}_{2} \mathrm{P}$ and $\mathrm{CO}_{2} \mathrm{P}$ was for samples prepared from (CMC $2 \%$ ) and sample (CMC $\left.2 \%+1.5 \% \mathrm{ThO}\right)$ respectively.

Table 5: Gas Permeability for edible films dried using solar dryer and electric dryer.

\begin{tabular}{|c|c|c|c|c|}
\hline \multirow[b]{2}{*}{ Samples } & \multicolumn{4}{|c|}{ Gas permeability, $\mathbf{m}^{3} \cdot \mathrm{m} / \mathrm{m}^{2}$.day.mmHg } \\
\hline & $\begin{array}{c}\mathrm{O}_{2} \mathrm{P} \text { Using } \\
\text { solar drying } \\
\left(\times 10^{-7}\right)\end{array}$ & $\begin{array}{c}\mathrm{O}_{2} \mathrm{P} \text { Using } \\
\text { electric drying } \\
\left(\times 10^{-7}\right)\end{array}$ & $\begin{array}{l}\mathrm{CO}_{2} \mathrm{P} \text { Using solar } \\
\text { drying }\left(\times 10^{-7}\right)\end{array}$ & $\begin{array}{l}\mathrm{CO}_{2} \mathrm{P} \text { Using } \\
\text { electric drying } \\
\left(\times 10^{-7}\right)\end{array}$ \\
\hline CMC 2\% & 9.21 & 5.04 & 7.07 & 1.3 \\
\hline CMC2\%+0.5\% ThO & 3.289 & 3.947 & 1.4 & 1.12 \\
\hline CMC2\%+1.0\% ThO & 2.631 & 3.65 & 1.85 & 1.7 \\
\hline CMC2\%+1.5\% ThO & 4.523 & 5.197 & 1.11 & 0.6 \\
\hline CMC2\%+2.0\% ThO & 1.578 & 3.157 & 0.6 & 0.432 \\
\hline
\end{tabular}

${ }^{*} \mathrm{O}_{2} \mathrm{P}$ oxygen permeability, $\mathrm{CO}_{2} \mathrm{P}$ carbon dioxide permeability

\section{Conclusion}

Samples of $\mathrm{CMC}$ and $\mathrm{CMC}$ with the addition of thyme oil were prepared and dried using electric dryer and solar dryer. Different properties of edible films were characterized (Transparency, solublity, Gas and water vapor permeability, mechanical properties). The results showed that drying using solar dryer decreased time of drying and had an effect on properties of edible films with respect to electric drying. $\mathrm{O}_{2}$ permeability were less in samples dried using solar energy while, transmittance rate, $\mathrm{CO}_{2}$ and water vapor permeability were increased in samples dried using solar dryer with respect to samples dried using the electric dryer). The addition of oil to CMC changed the structure of edible 
film and the tensile strength for edible film was higher for control sample (CMC) while it did not give a good trend when adding thyme oil.

\section{References}

ASTM, 1996. Test methods for tensile properties of thin plastic sheeting, D882-91. Annual book of ASTM. Philadelphia, PA: American Society for Testing and Materials.

Atanu B., R. F. Furtado, M. do Socorro Rocha Bastos, S. D. Benevides, M. de Albuquerque Oliveira, V. Boddul and H. N. Cheng, 2018. Preparation and Characterization of Carboxymethyl Cellulose Films with Embedded Essential Oils. Journal of Materials Science Research, 7(4): 1625

Baser, K.H.C and G. Buchbauer, 2015. Handbook of essential oils: science, technology, and applications. CRC Press, 1128.

García, M.A., M.N. Martino, and N.E. Zaritzky, 2000. Lipid addition to improve barrier properties of edible starch-based films and coating, Journal of Food Science, 65, 941-947.

Gontard, N., S. Guilbert, and J. Cuq, 1992. Edible wheat gluten films: influence of the main process variables on films properties using response surface methodology. Journal of Food Science, 57, 190-195.

Khaled S.A.N. and Manal A. Sorour, 2019. Evaluation of Permeation Cell for measuring Edible and Active Films Gas Permeability, Journal of Engineering and Applied Sciences, 4(12):402-4026.

Kokoszka, S., F. Debeaufort, A. Lenart, and A. Voilley, 2010. Water vapor permeability, thermal and wetting properties of whey protein isolate based edible films. International Dairy Journal, 20, 5360 .

Liu D, and L. Zhang, 2006. Structure and properties of soy protein plastics plasticized with acetamide. Journal of Macromolecular Materials and Engineering, 291(7):820-8.

Nandane, A. S., and R. K. Jain, 2011. Effect of composite edible coating on physicochemical properties of tomatoes stored at ambient conditions. International Journal of Advanced Engineering Technology, 2(4), 211-217.

Nooshin N., B. Ghanbarzadeh, C. Gardrat, M. R. Rezaei, M. Hashemi, C. Le Coz, V. Coma, 2017. Cinnamon and ginger essential oils to improve antifungal, physical and mechanical properties of chitosan-carboxymethyl cellulose films. Journal of Food Hydrocolloids, 70 , 36-45.

Oliveira, M. A., M. S. R. Bastos, H. C. R. Magalhaes, D. S. Garruti, S. D.Benevides, R. F. Furtado, and A. S. Egito, 2017. $\alpha, \beta$-citral from Cymbopogon citratus on cellulosic film: Release potential and quality of coalho cheese. LWT Food Scince. Technology, 85, 246-51.

Otoni, C. G., M. R. de Moura, , F. A. Aouada, , G. P. Camilloto, R. S.Cruz, M. V. Lorevice, N. F. F. Soares, and L. H. C. Mattoso, 2014. Antimicrobial and physical-mechanical properties of pectin/papaya puree/cinnamaldehyde nanoemulsion edible composite films. Food Hydrocoll., 41, 188-94.

Soltani, M. Alimardani F. Moisture content prediction of Iranian wheat using dielectric technique. Journal of food science and technology. 2014; 51(11):3500-4.

SuppakulP "Moisture sorption characteristics of cassava flour film. Proceedings of the $15^{\text {th }}$ IAPRI World Conference on Packaging". International Association of Packaging Research Institutes, Tokyo, (2006) ,113-117. 